\title{
Historicizing Joseph Conrad's Heart of Darkness: A Critique of King Leopold II's Colonial Rule
}

\author{
Isam Shihada ${ }^{1}$ \\ ${ }^{1}$ Associate Professor of English Literature and Gender Studies, Department of English, Gaza Strip, Palestine \\ Correspondence: Isam Shihada, Associate Professor of English Literature and Gender Studies, Department of \\ English, Gaza Strip, Palestine. E-mail: isams@hotmail.com
}

\author{
Received: October 26, 2014 Accepted: January 4, 2015 Online Published: February 25, 2015 \\ doi:10.5539/ells.v5n1p13 URL: http://dx.doi.org/10.5539/ells.v5n1p13
}

\begin{abstract}
This study examines how Conrad's Heart of Darkness has played an important role in exposing the brutal reality of Belgian colonialism in the Congo Free State under the pretense of a civilizing mission. The study focuses on how Conrad's Heart of Darkness has been instrumental in revealing the atrocities committed by King Leopold II's agents in their desperate scramble for the rich resources of the Congo, such as ivory and rubber. King Leopold II's atrocities may account for the death of almost ten million Congolese natives, a crime of a genocidal scale, which has terribly affected the people of the Congo to this day. Conrad renders his own anti-colonial critique through his central character, Charles Marlow, who learns about the brutal methods of Belgian colonialism while on a journey to the Congo searching for the infamous ivory agent, Kurtz. The study examines how Conrad's Heart of Darkness critiqued King Leopold II's colonial rule and contributed to the launching of an international protest which exposed and put an end to the genocide committed against the Congolese in the name of civilization, science, and progress. The campaign eventually forced King Leopold II to quit the Congo Free State in 1908, and unraveled one of the most heinous crimes in history committed under the pretext of "civilization".
\end{abstract}

Keywords: Joseph Conrad, Heart of Darkness, colonialism, King Leopold II, The Congo Free State

\section{Introduction}

For Joseph Conrad, Africa is a symbol of the unknown, an unsolved mystery which he loved to explore since his childhood. Hence, we always observe Conrad dreaming of visiting Africa. Indeed, Conrad described seeing it on a map and indicating the blank space, signifying the mystery of Africa, and expressed his wish to go there one day (Conrad, 2010). In the 1890s, there was widespread news in London about Henry Stanley's successful Emin Pasha Relief Expedition (Note 1). During these times, Conrad searched tirelessly for a job at sea to fulfill his childhood fantasies of sailing to Africa. When Conrad arrived back in Brussels, he applied for working on the Congo River.

At the height of the colonial campaigns of Britain, France, Portugal, Holland, and Belgium, Joseph Conrad, like everyone else in Europe, had been instilled with a belief that these colonial campaigns were conducted to civilize and educate the ignorant people of Africa and Asia. These campaigns were also perceived as a noble cause motivated by the call of duty and Victorian moral sensibilities. In 1890, Joseph Conrad was appointed as the captain of a steamer on the Congo River by a Belgian trading company. He had sailed on a ship carrying the first batch of rails and ties for the construction of a railway over the Crystal Mountains, from the sea to Stanley Pool, from which boat steamers could sail to the heart of Africa. With regard to the railway over the Crystal Mountains, it was King Leopold II who promoted and financed Henry Stanley's plan of constructing the railway in order to control every part of the Congo basin. Stanley "would first set up a base near the river's mouth and then construct a road around the rapids, through the rugged Crystal Mountains - a precursor to a railway" (Hochschild, 1999, p. 38).

Joseph Conrad's trip to the Congo (Note 2) was arguably a revelation for him. During his journey, Conrad noted "evidence of atrocities, exploitation, inefficiency, and hypocrisy, and it fully convinced him of the disparity between imperialism's rhetoric and the harshest reality" (Watts, 1996, p. 48) of imperialist plundering and looting. Conrad also witnessed forced labor and corruption perpetrated by King Leopold II's (Note 3) agents and his Force Publique (Note 4) in the Congo. This leads us to examine the relationship between King Leopold II 
and the Congo Free State.

\section{King Leopold II and the Congo Free State}

King Leopold's desire for colonial control in Africa is tangibly demonstrated by his tenacious lobbying and bargaining to secure a place for himself during the frantic European scramble to colonize Africa.

In the 1890s, the Congo was referred to as the Congo Free State while under the absolute control of King Leopold II of Belgium. Leopold was able to claim the Congo by lobbying, maneuvering, and convincing other European powers like Britain, France, and Germany that he was involved in a philanthropic and civilizing mission in the Congo. In his opening address of the conference in Brussels, King Leopold II explained that the conference's aim was "to open to civilization the only part of our globe which it has not yet penetrated, to pierce the darkness which hangs over entire peoples, is, I dare say, a crusade worthy of this century of progress" (Hochschild, 1999, p. 44). For Leopold, it was a holy mission to enlighten and civilize the lives of the Congolese natives. Hence through the use of several sham organizations (Note 5), Leopold was able to lay claim to the Congo, an area almost the size of Europe. Within this context, Peter Eichstaedt (2011) argues that by claiming the Democratic Republic of the Congo as his personal property in the 1870s, Leopold sets "in motion one of the most monstrous plunders ever by a colonial power. Ivory, gold, rubber, and an array of minerals were taken in his name, along with millions of lives" (p. 1).

In fact, the colonial scramble for Congo, in particular, and Africa, in general, ironically starts with slogans such as abolishing slavery, and civilizing and weaning the ignorant African natives in an attempt to divide the wealth of Africa (Note 6). In this regard, Adam Hochschild (1999) states that, "in the nineteenth-century European drive for possessions in Africa, people justified colonialism in various ways, claiming that it Christianized the heathen or civilized the savage races or brought everyone the miraculous benefits of free trade" (p. 38). The moral rationalizations of the civilizing mission were therefore used by European colonialists to justify colonialism. Moreover, the effort to Christianize and civilize the heathen and the savage races may explain why these colonial campaigns are usually preceded by Catholic and Protestant missionary missions in the colonized areas like the mission of David Livingstone in the Congo (Note 7).

King Leopold II's infamous reign in the Congo was notably marred by brutality, the mistreatment of the natives, and the deliberate plundering and looting of natural resources such as ivory and rubber. For example, villagers were terrorized and forced into extracting ivory and tapping rubber. If they failed to collect the required quotas, they were severely punished. The hands of the Congolese were cut and collected in baskets by King Leopold II's agents to account to their masters for used ammunition since it was so expensive to exportit overseas (Note 8).

Ivory and rubber were collected for export by Leopold's agents although his so called purpose was to civilize and educate the natives and abolish slavery. Consequently, it turned out to be a war of enslavement of the Congolese natives. For example, King Leopold II considered forced labor "the only way to civilize and uplift these indolent and corrupt peoples of the Far East" (Hochschild, 1999, p. 37). Furthermore, to fulfill his colonial aspirations, we find that Leopold took Holland as an example of a small country which managed to accumulate vast wealth out of its colonies. It was time for Belgium to perfect the art of exploiting colonies if it were to survive among the larger colonial powers such as France and Britain.

\section{Historicisizing Joseph Conrad's Heart of Darkness: A Critique of King Leopold II's Colonial Rule}

After spending six memorable yet hellish months in the Congo, one may argue that witnessing the murder, forced labor, and other atrocities committed by King Leopold II's agents in the Congo Free State inspired Joseph Conrad to write his novella, Heart of Darkness. Conrad's experience most certainly provided "a basis for the indignation" of Heart of Darkness (Watts, 1996, p. 48).

Conrad's trip may also account for his realistic depiction of the atrocities perpetrated in the Congo Free State, summed up in Conrad's own words: "Heart of Darkness is experience ... pushed a little (and only very little) beyond the actual facts of the case" (Conrad, 1999, p. 64). The fact that Conrad had lived for a few months in the Congo "gives Heart of Darkness an authenticity that undoubtedly has contributed to its enduring power and appeal" (Firchow, 2002, p. 22). In other words, Heart of Darkness was actually based on real events and people Conrad either saw or heard about.Therefore, a historical understanding of the Congo Free State is crucial to our understanding of Heart of Darkness and its implicit messages.

In this study, I would like to examine how Conrad's Heart of Darkness has played an important role in exposing the brutal reality of colonialism under the pretense of a civilizing mission. The study focuses on how placing Conrad's Heart of Darknessin a historical context has been instrumental in uncovering atrocities committed by King Leopold's agents to loot and extract the rich resources of the Congo like ivory and rubber, "which may, in 
turn, account for the death of almost ten million Congolese natives" (Hochschild, 2005, p. 40). This is a crime of a genocidal scale (Note 9) having lasting effects on the Congo and its people till date. My argument is that Conrad's Heart of Darkness is a critique of Belgian colonialism and its extensive impact. Conrad renders his own anti-colonial critique through his central character, Charles Marlow. We observe that Marlow learns of the real motives and brutal methods of colonialism while he is on a journey to the Congo, searching for the infamous ivory agent, Kurtz.

For Edward Said (2008), Conrad's Heart of Darkness provides "an extraordinary account of the imperial attitudes of conquest and the tremendous devastation that accompanied it" (p. xiii). Conrad's account of colonial devastation in the Congo is supported by his trip to the Congo in 1890, which causes him to feel disillusioned about colonialism and its real motives. These colonial motives were a contradiction to how it was perceived and discussed in Europe, which ironically coined it as the "white man's burden." (Note 10) It is a sobering journey for Conrad, which turned out to be a nightmare rather than the romantic dream he had always cherished since his childhood. Joseph Conrad reviewed his feelings after landing in the Congo: "A great melancholy descended on me. Yes, this was the very spot. But there was...only the unholy recollection of a prosaic newspaper stunt and the distasteful knowledge of the vilest scramble for loot that ever disfigured the history of human conscience and geographical exploration. What an end to the idealized realities of a boy's daydreams!" (Curle, 1926, p. 10)

Conrad's romantic dream of seeing the exotic land of Africa was shattered, and the noble concept of the "white man's burden" ironically turned into a disgusting crime of looting and robbing people of their natural resources, destroying humanity and lives. It was an experience which moved Conrad from unconsciousness to self-awareness. Conrad's experience in the Congo had, in fact, magnified his revulsion towards and wariness of imperialism; it served as a reminder of the "Russian Empire which destroyed his family and ravaged his childhood" (Fincham \& Hooper, 1996, p. 43). Conrad's inherent skepticism about colonialism can be related to the fact that he was born into a country (Poland) which had been invaded by Austria, Prussia, and Russia. Moreover, his parents were Polish nationalists exiled by Russian authorities due to their political views.

With regard to colonialism, we find that the colonial modus operandi of looting and extortion was supported by an oriental ideology which granted colonial powers the right to control other people merely because they had different complexions or cultures. Such policies caused Conrad to disapprove the whole colonial project through his mouthpiece, Marlow. Indeed, Marlow remarks: "The conquest of the earth, which mostly means the taking it away from those who have a different conception or slightly flatter noses than ourselves, is not a pretty thing when you look into it too much" (Note 11) (Conrad, 1902, p. 13). This passage reflects how Marlow, like his author Joseph Conrad, is tremendously appalled by the extent of brutality and greed seen among the Belgian colonialists in the Congo, so much so that his view of colonialism and its real motives were permanently transformed. It makes Marlow wonder who gives us the right to colonize and persecute other people, just because they are simply different from us!

For Hunt Hawkins, Conrad is critical of Belgian imperialism and shows his sympathy for Africans since they are, like Europeans, human. He adds that Conrad rejected imperialism "because it disrupted indigenous cultures" (Peters, 2013, p. 97). In Heart of Darkness, we find the narrator, Charles Marlow, is employed by an ivory trading company to captain a steam boat sailing to the Congo River, whose shape appeared as "an immense snake uncoiled, with its head in the sea, its body at rest curving afar over a vast country and its tail lost in the depths of the land" (p. 16).

Marlow's destination is a post where the company's ambitious agent, Mr. Kurtz, is stationed. It is rumored that Kurtz has amassed huge quantities of ivory employing unspeakable means of cruelty, oppression, and violence against the native Congolese. Marlow's journey is an enlightening experience which gradually makes him see the brutal reality of colonialism and its destructive impact on both the colonizer and the colonized, stripping both of their humanity.

During his trip to the Congo, Marlow realizes that the situation is completely contrary to what is propagated at home about the great work done by Belgian colonists in civilizing ignorant people, as Marlow's aunt is led to believe. Ironically, it is a panorama of brutality. In his first encounter with the truly abominable nature of colonialism, we observe Marlow pass by a group of laborers working on constructinga railway over the Crystal Mountains:

A slight clinking behind me made me turn my head. Six black men advanced in a file toiling up the path. They walked erect and slow, balancing small baskets full of earth on their heads, and the clink kept time with their footsteps .... I could see every rib, the joints of their limbs were like knots in a rope, each had an iron collar on his neck and all were connected together with a chain whose bights swung between them, rhythmically clinking 
(p. 31).

In this passage, we see Marlow appalled and shocked by the dehumanization of the chained Congolese, who are constructing a railway and involuntarily contributing to white expansionism. Phrases like "every rip" and "the joints ... were like knots in a rope" indicate the miserable health of the workers. We see emaciated, chained black prisoners who are being marched to work. They are chained like animals, which imply the nature of their forced labor. In another incident, we see Marlow meet several starving railway workers who have crawled away to die. Marlow saw "now and then a carrier dead in harness, at rest in the long grass near the path, with an empty water-gourd and his long staff lying by his side" (p. 39). Here, Conrad raises the question of forced labor and the oppressive and inhuman conditions Congolese laborers endured. They were reduced to mere animals where they were left to starve and die miserably. In another instance, Marlow observes the "body of a middle-aged negro, with a bullet-hole in theforehead" (p. 40) lying beside the road. He also hears a black worker screaming horribly from being beaten for accidentally causing a fire: "A nigger was being beaten nearby. They said he had caused the fire in some way; be that as it may, he was screeching most horribly" (p. 47). Furthermore, during his walk around the Rapids, Marlow describes how people fled their villages to avoid conscription as porters and collectors of ivory and escaping the brutality of Kurtz:

The population had cleared out a long time ago. Well if a lot of mysterious niggers armed with all kinds of fearful weapons suddenly took to traveling on the road [in England] between Deal and Gravesend catching the yokels right and left to carry heavy loads for them, I fancy every farm and cottage thereabouts would get empty very soon.... I passed through several abandoned villages (p. 39).

Marlow sees abandoned villages whose inhabitants fled deep into the forests to escape being enslaved. They were afraid of retribution from Kurtz, a representative example of King Leopold II's Force Publique, who killed, cut hands, systematically raped women, and burned houses. In addition, villagers were either killed or left to die deep in the forest due to a lack of healthy food and disease if orders were disobeyed. Marlow has no whims about why this brutality is tolerated. It is Belgian colonialism, which is described by Marlow as the conquest of those who are different from us, under the guise of "the philanthropic pretense" (p. 47).

The cleared villages and brutality make Marlow wonder what would happen to the English countryside if it were similarly subjected to African imperialism. "I fancy every farm and cottage thereabouts would get empty very soon.... if a lot of mysterious niggers armed with all kinds of fearful weapons suddenly took to travelling on the road between Deal and Gravesend (p. 39) The English villagers will obviously clear out their villages fearing for their lives and safety of their families, exactly as done by the Congolese villagers. For Marlow, the comparison between Europeans and Africans underscores their equal humanity and confronts the idea that there is nothing such as a lesser person as claimed by Orientalist colonial ideology.

In addition, Conrad's Heart of Darkness renders a harsh critique of King Leopold's colonial policy which is based on blood, forced labor, and tyranny in return for loads of precious ivory. For instance, Marlow narrates how the Leopoldian colonial economy works: "a stream of ... rubbishy cottons, beads, and brass-wire [were sent] into the depths of darkness and in return came a precious trickle of ivory" (p. 36). Thus, it seems that ivory was taken from the Congo in exchange for some cheap beads and cotton (Note 12). In 1890, ivory still constituted the core aspect of the Congo's economy before the discovery of rubber and other mineral resources. Ivory is ironically described by Marlow as an idol colonialists pray for: "The word 'ivory' rang in the air, was whispered, was sighed. You would think they were praying to it" (p. 46). It was also every agent's dream to get appointed to a trading post "where ivory was to be had, so that they could earn percentages" (p. 46). This passage may be referring to the system of commissions bestowed on King Leopold's agents to encourage them to extract more ivory by any means.

When it comes to Conrad's character, Kurtz, we find that he represents the image of the "lone white agent far up the great river, with his dreams of grandeur, his great store of precious ivory, and his fiefdom carved out of the African jungle" (Hochschild, 1999, p. 144). Kurtz's shadowy nature is spurred by something dark which lurks deep in Africa, a dark force which lures Kurtz and leaves him unrestrained: you "can't judge Mr. Kurtz as you would an ordinary man" (p. 113). This dark force which we perceive in Kurtz and is present in Africa cannot be separated from the symbolism with the concept of colonialism and its brutal methods and agents. In other words, it reflects the darkness of the so called civilizing mission itself. Kurtz can also be perceived as an example of colonial "Europeans who have brought an unknown inhumane behavior that seared the soul of the continent" (Eichstaedt, 2011, p. 211) and who tragically sealed the future of millions of people who lived in Africa during King Leopold II's reign.

One may argue that Conrad's Kurtz is the incarnation of human exploitation, as well as that of the evil spirit of 
King Leopold II and his merciless colonial expansion in the Congo. Historically speaking, Kurtz's character was inspired by several agents (Note 13) whose sole mission was to make quick money and to collect large amounts of precious ivory to send back to Belgium. Kurtz's character might be based on Captain Leon Romof the Force Publique, whom Joseph Conrad met at Stanley Falls in 1890. When Conrad "passed through Leopoldville, the station chief there was Leon Rom" (Hochschild, 1999, p. 147). The scene of a collection of heads of Congolese rebels surrounding Kurtz's House, their "heads on the stakes... [looking] black, dried, sunken, with closed eyelids" (p. 113) reminds us of Captain Rom whose bed was similarly decorated by the heads of Congolese rebels collected after a merciless military expedition against Congolese rebels and their families.

Linking the character of Kurtz to captain Leon Rom may illustrate the significance of a historical perspective in reading Conrad's Heart of Darkness, particularly if we want to completely grasp the scale of genocide in the Congo practiced by King Leopold II. For example, we see Marlow, on the steamboat, looking through binoculars at what he thinks are ornamental knobs atop the fence posts in front of Kurtz's house, and then, to his horror, finds that each is only a severed head - "black, dried, sunken, with closed eyelids - a head that seemed to sleep at the top of that pole, and, with the shrunken dry lips showing a narrow white line of the teeth..." (p. 113). It seems as if Kurtz had a fondness for shrunken heads since his fence posts were ornamented with them. These skulls belonged to the Congolese rebels who refused to comply with Kurtz's orders or who complied but failed to produce the designated quota of ivory. They were consequently punished by execution. Furthermore, we understand that Kurtz's decoration of his house with heads could be a sign of power and a stern warning that this will be the same fate for those who refuse to obey orders or fail to collect ivory. Within this context, Michiko Kakutani (1998) writes that Conrad's Heart of Darkness records in detail "the actual facts of King Leopold II's brutal rule of Congo in 1890, just as one of history's most heinous acts of mass killing was getting under way" (p. $1)$.

Indeed, King Leopold II's hypocrisy is seen in the way he calls his agents "all powerful protectors and benevolent teachers who are engaged in the work of material and moral regeneration" (Brunner \& Mills, 2003, p.8). Therefore, we find Kurtz perceiving himself as a defender of high principles and an author of a report on "The Suppression of Savage Customs." It is ironically the same prevalent Oriental thinking to which Marlow's aunt subscribes when Marlow bids her goodbye before sailing to the Congo. She talked about "weaning those ignorant millions from their horrid ways" (p. 24), to the extent of making Marlow feel uncomfortable. He was about to confess to her that "the company was run for profit" (p. 24).

Similarly, we observe that King Leopold II's agents go about exploiting and looting the Congo in the errant belief that they are civilizing the population and serving "the noble cause" (p.17). For example, besides being a killer, Kurtz is portrayed as an intellectual "emissary of pity, and science, and progress" (p. 50). He is also depicted to be an artist who paints "a small sketch in oils, on a panel, representing a woman, draped and blindfolded, carrying a lighted torch" (p. 49).

Kurtz's portrayal of being both a killer and a messenger of progress and science may symbolize the colonial strategy of colonizing other countries, being a combination of both cultural and colonial conquest (Note 14). Kurtz's intellectual pretensions helped him succeed in "getting himself adored" (p. 112) by the Congolese natives in the inner station. "[L]et us say ... nerves ... went wrong, and caused him to preside at certain midnight dances ending with unspeakable rites" (p. 100). Here, we see that tribal chiefs crawl on the ground before Kurtz engaging in unspeakable rites, where people obey him with a slavish devotion. They worship him as a demigod. Kurtz himself is involved in unspeakable and shocking rituals which Marlow refuses, out of disgust, to report. It is said that "the rituals involve human sacrifice and the subsequent consumption of a portion of the sacrificial victim" (Moore, 2004, p. 192).

At one stage in Heart of Darkness, the International Society for the Suppression of Savage Customs asks Kurtz to write a report on the superiority of white Europeans. Kurtz's report is a reflection of white European superiority, which Kurtz wants the others to follow and worship. It may represent the Belgian colonial strategy adopted by King Leopold II. Kurtz begins his report by arguing the following:

We whites, from the point of development we had arrived at, 'must necessarily appear to them [savages] in the nature of supernatural beings - we approach them with the might as of a deity,' and so on, and so on. 'By the simple exercise of our will we can exert a power for good practically unbounded' (p. 100).

Kurtz ends his report, scrawling with a shaky hand, with an appeal to "every altruistic sentiment it blazed at you, luminous and terrifying, like a flash of lightning in a serene sky: 'Exterminate all the brutes!'” (p. 101). The order by Kurtz to exterminate all the "brutes" may reveal a genocidal motive behind Kurtz's proclaimed 
missionary benevolence. It may be interpreted as "a satirical parody of King Leopold's speeches on the Belgian's civilizing work in the Congo Free State" (Peters, 2010, p. 147).

King Leopold II's brutality and his colonial conquest of the Congo is whispered by Kurtz while dying: "The horror! The horror!" (p. 142). His final words reflect the sheer horror experienced by the Congolese population who has faced the bitter choice of either working to death or being exterminated. They are "virtually enslaved and cruelly maltreated in the quest for rubber and ivory" (Bloom, 2011, p. 29). It is also a clear message to the world that what is happening in the Congo is horrible beyond imagination and must stop immediately. Conrad's revulsion at the scale of the genocidal slaughter seen in the Congo is uniquely expressed. His literary genius allows us to "grasp the numbing regularity in which the slaughter was carried out" (Brunner \& Mills, 2003, p. 8).

For Conrad, Kurtz is an imperialist. He is a symbol of imperialism and its darkness. His excesses "are portrayed as the natural extension of a system of extracting ivory at any cost" (Brunner \& Mills, 2003, p. 7). He is also an arch European, since "All Europe contributed to the making of Kurtz" (p. 100). Interestingly, Kurtz's ancestry is half French and half English, symbolizing the most powerful colonial powers at that time. Finally, Conrad's Heart of Darkness and its character, Kurtz, "are the creations not just of a novelist but of an open-eyed observer who caught the spirit of a time and place with piercing accuracy" (Hochschild, 1999, p. 152).

\section{Conclusion}

Despite the criticism leveled by both Achebe (Note 15) and feminists like Straus (Note 16) against Conrad and his novella, Heart of Darkness, Conrad's work has been instrumental in underscoring the Congolese cause by depicting the atrocities committed, and honestly depicting "the murderous exploitation of the Congo by Belgium's King Leopold [which had] attained almost mythic status" (Jones, 2006, p. 42). Consequently, Heart of Darkness has contributed to the launch of an international campaign (Note 17) that strove to expose and end the genocide committed against the Congolese.

Furthermore, Joseph Conrad personally participated in aninternational campaign to save lives in the Congo. For instance, Conrad sent letters of support to Roger Casement who, in turn, submitted a parliamentary report documenting crimes against humanity committed by King Leopold II in the Congo. Joseph Conrad's Heart of Darkness explored the plight of the Congolese natives, confirming the revolutionary role of literature in enhancing our lives and alleviating our suffering. It emphasized Conrad's awareness that "the novelist is a historian, the preserver, the keeper, the expounder of human experience" (Panichas, 2007, p. 156). Moreover, Conrad's role as a novelist, a public intellectual, and a defender of human rights along with the efforts of activists like E. D. Morel and Roger Casement (Note 18) have, in fact, stirred an international outcry for world powers to intervene and stop the ongoing genocide in the Congo. This publicity eventually forced King Leopold II to relinquish the Congo Free State to the Belgian government in 1908.

This activism also paved the way for Belgian authorities to investigate Belgium's colonial legacy and the well documented claims of genocide (Note 19) committed in the Congo. It is noted that during King Leopold's rule, countless deaths were attributed to forced labor, merciless killing, and sleeping sickness (Note 20).

Finally, Conrad's Heart of Darkness has proved to be "“ahead of its time' and exceptionally proleptic text." (Watts, 1996, p. 48) in rendering an extraordinary critique of colonialism, exposing its truly brutal nature and its lasting impact on the Congolese people who were left to suffer and still experience the effects of colonialism today (Note 21). Conrad's Heart of Darkness was a polemic for stopping genocide in the Congo. Simultaneously, it called for respecting the human rights of the Congolese, our brothers in humanity.

\section{References}

Bloom, H. (Ed.). (2010). Joseph Conrad. New York: Infobase Publishing.

Conrad, J. (1902). Heart of Darkness. Virginia: University of Virginia Press.

Conrad. J. (2008). A Personal Record. Cambridge: Cambridge University Press. http://dx.doi.org/10.1017/CBO9781107341012

Curle, R. (Ed.). (1926). Last Essays. London: J.M.Dent \& Sons.

Eichstaedt, P. (2011). Consuming the Congo: War and Conflict Minerals in the World's Deadliest Place. Chicago: Chicago Review Press.

Fincham, G., \& Myrtle, H. (1996). Under Postcolonial Eyes: Joseph Conrad after Empire. Claremont: Juta and Company Ltd. 
Firchow, P. E. (2000). Envisioning Africa: Racism and Imperialism in Conrad's Heart of Darkness. Kentucky: University Press of Kentucky.

Goonetilleke, D. C. (2009). Joseph Conrad's Heart of Darkness: A Routledge Study Guide. Routledge.

Hochschild, A. (1999). King Leopold's Ghost: A Story of Greed, Terror, and Heroism in Colonial Africa. New York: Houghton Mifflin Harcourt.

Hochschild, A. (2005). In the Heart of Darkness. New York Review of Books, (15), 39-42. Retrieved October 1, 2014, from http://www.nybooks.com/articles/archives/2005/oct/06/in-the-heart-of-darkness/

Jones, A. (2006). Genocide: A Comprehensive Introduction. London: Routledge. http://dx.doi.org/10.4324/9780203347447

Kakutani, M. (1998). Genocide with Spin Control: Kurtz Wasn't Fiction. New York Times. Retrieved from http://www.nytimes.com/1998/09/01/books/books-of-the-times-genocide-with-spin-control-kurtz-wasn-t-fic tion.html

Mills, N., \& Brunner, K. (2004). The New Killing Fields: Massacre and the Politics of Intervention. New York: Basic Books.

Moore, G. M. (2004). Joseph Conrad's Heart of Darkness: A Casebook. Oxford University Press.

Panichas, G. A.(2007). Joseph Conrad: His Moral Vision. GA: Mercer University Press.

Peters, J. (2010). A Historical Guide to Joseph Conrad. Oxford: Oxford University Press.

Peters, J. (2013). Joseph Conrad's Critical Reception. Cambridge: Cambridge University Press. http://dx.doi.org/10.1017/CBO9781139542296

Said, E. (1966). Joseph Conrad and the Fiction of Autobiography. New York: Columbia University Press.

Stape, J. H. (Ed.). (1996). The Cambridge Companion to Joseph Conrad. Cambridge: Cambridge University Press. http://dx.doi.org/10.1017/CCOL0521443911

Stape, J. H. (Ed.). (2014). The New Cambridge Companion to Joseph Conrad. Cambridge: Cambridge University Press. http://dx.doi.org/10.1017/CCO9781139547451

Watts, C. (1996). "Heart of Darkness". In J. H. Stape (Ed.), The Cambridge Companion to Joseph Conrad (pp. 45-63). Cambridge: Cambridge University Press. http://dx.doi.org/10.1017/CCOL0521443911.003

\section{Notes}

Note 1. Henry Morton Stanley's exploration of the Congo region at the invitation of Leopold II led to the establishment of the Congo Free State under Leopold's personal sovereignty.

Note 2. For more information on Joseph Conrad's trip to the Congo, see Bloom, H. (Ed.). (2011). Joseph Conrad. New York: Info base Publishing.

Note 3. For more information on King Leopold II, see Ewans, M. (2002). European Atrocity, African Catastrophe: Leopold II, the Congo Free State and its Aftermath. London: Routledge; Ascherson, N. (2001). The King Incorporated: Leopold the Second and the Congo. London: Granta Books; Hochschild, A. (1999). King Leopold's Ghost: A Story of Greed, Terror, and Heroism in Colonial Africa. New York: Houghton Mifflin Harcourt.

Note 4. For more information on Force Publique and its atrocities, see Vandervo, B. (2009). Wars of Imperial Conquest in Africa, 1830-1914. Indiana: Indiana University Press; Nzongola-Ntalaja, G. (2002). The Congo: From Leopold to Kabila: A People's History. London: Zed Books.

Note 5. In 1876, Leopold II hosted a geographic conference in Brussels, inviting famous explorers and philanthropists to stir up interest in a "humanitarian" endeavor for Europeans in Central Africa to improve and civilize the lives of Congolese natives.

Note 6. With regard to European representations of Africa, see Said, E. (1978). Orientalism. Vintage Books: New York; Fanon, F. (1968). Black Skin White Masks. Pluto Press: London; Fanon F. (1967). The Wretched of the Earth. Pluto Press: London; WaThiong'o, N. (1994). Decolonizing the Mind: The Politics of Language in African Literature. Kenya: East African Publishers.

Note 7. David Livingstone was a Scottish Congregationalist medical missionary with the London Missionary Society and an explorer in Africa. 
Note 8. For more information on crimes committed in the Congo for the sake of ivory and rubber, see Glassman, J. (2011). War of Words, War of Stones: Racial Thought and Violence in Colonial Zanzibar. Bloomington: Indiana University Press; Ndlovu-Gatsheni, S. J. (2013). Coloniality of Power in Postcolonial Africa. Myths of Decolonization. Dakar: Codesria Book Series; Vanthemsche, G. (2012). Belgium and the Congo, 1885-1980. Cambridge: Cambridge University Press.

Note 9. When it comes to the question of genocide, it is about "processes by which hundreds of millions of people met brutal ends." (Jones, 2006, p. xix). Until the Second World War, genocide was defined as "a crime without name." It was only coined and placed in a global and historical context by Raphael Lemkin.

Note 10. The "White Man's Burden" is a poem by the English poet Rudyard Kipling. It is interpreted to mean that white people have an obligation to rule over, and encourage the cultural development of, people from other cultural backgrounds until they can take their place in the world economically and socially.

Note 11. All references will be henceforth taken from Conrad, J. (1902). Heart of Darkness. Virginia: University of Virginia Press.

Note 12. In 1900, Edmund Morel, a human rights activist, noticed that ships that brought vast loads of rubber from the Congo returned only with guns and ammunition for the Force Publique.

Note 13. For more on King Leopold II's agents, see Ray, M. (2010). Joseph Conrad: Interviews and Recollections. Iowa: University of Iowa Press; Orr, L., \& Theodore, B. (Eds.). (1999). A Joseph Conrad Companion. CT: Greenwood Publishing Group; Mills, N., \& Brunne, K. (Eds.). (2003). The New Killing Fields: Massacre and the Politics of Intervention. New York: Basic Books.

Note 14. For more on the role of culture and colonialism, see Said, E. (1993). Culture and Imperialism. New York: Random House, LLC.

Note 15. With regard to Achebe's criticism of Conrad's Heart of Darkness and the question of African representation, see Achebe, C. (1978). An image of Africa. Research in African Literatures, 9(1), 1-15.

Note 16. With regard to the feminist criticism of Conrad's Heart of Darkness and the question of the representation of the woman, see Straus, N. P. (1987, January). The Exclusion of the Intended from Secret Sharing in Conrad's "Heart of Darkness". In Novel: A Forum on Fiction (pp. 123-137). Brown University.

Note 17. The international campaign and the Congo Reform Association were led by dedicated individuals like Joseph Conrad, Sir Arthur Conan Doyle, E. D. Morel and Sir Roger Casement.

Note 18. For more on E. D. Morel and Sir Roger Casement and their human rights activism, see Morel, E. D. (1920). The Black Man's Burden. New York: BW Huebsch; Hawkins, H. (1981). Joseph Conrad, Roger Casement, and the Congo Reform Movement. Journal of Modern Literature, 65-80.

Note 19. According to Belgian Commission estimates, during the "Leopold period and its immediate aftermath the population of the territory dropped by approximately 10 million people" (Jones, 2006, p. 3).

Note 20. During this time, the Congo Free State was swept by an epidemic of "sleeping sickness," one of the most disastrous plagues recorded in human history. The impact of this disease was exacerbated by slavery, privation, and other adverse conditions imposed by Leopold.

Note 21. Unfortunately, the Congo continues to be a land of chaos, massacres, and looting.The neo-colonial scramble is still going on for the Congo's natural resources including gold, timber, diamonds, tin, and coltan, which has turned the eastern parts of the Congo to permanent killing fields. For more information, see Stearns, J. (2011). Dancing in the Glory of Monsters: the Collapse of the Congo and the Great War of Africa. New York: PublicAffairs; Eichstaedt, P. (2011). Consuming the Congo: War and Conflict Minerals in the World's Deadliest Place. Chicago: Chicago Review Press; Prunier, G. (2008). Africa's World War: Congo, the Rwandan Genocide, and the Making of a Continental Catastrophe. Oxford:Oxford University Press.

\section{Copyrights}

Copyright for this article is retained by the author(s), with first publication rights granted to the journal.

This is an open-access article distributed under the terms and conditions of the Creative Commons Attribution license (http://creativecommons.org/licenses/by/3.0/). 